\title{
Peningkatan Kedisiplinan Belajar Peserta Didik Melalui Media Google Sites
}

\section{Pramesti Arumingtyas}

Universitas Sebelas Maret

pramestiarum@student.uns.ac.id

\section{Article History}

received 30/4/2021

\begin{abstract}
In the era of the COVID-19 pandemic, learning is done online (BDR). This learning system makes it quite difficult for teachers to monitor student learning activities directly. Unlike when learning takes place at school, teachers can ensure students can follow the set learning schedule. Therefore, teachers need to find solutions related to how to know the discipline of students in carrying out online learning at home. The purpose of this article is to 1) describe learning discipline in online learning, 2) google sites learning media in online learning, 3) the influence of google sites learning media on student discipline in online learning. The results of this study are 1) Learning discipline comes from the affective domain, which is one of the points of the value of integrity, which is included in the realm of Strengthening Character Education (PPK), 2) Google sites learning media can improve learning discipline through learning schedules and study hours that included, and can monitor attendance discipline, listen to the material, and collect assignments given.
\end{abstract}

Keywords: learning dicipline, learning media, google sites, online learning

\begin{abstract}
Abstrak
Pada era pandemi covid 19 pembelajaran dilakukan secara online (BDR). Sistem pembelajaran ini membuat guru cukup kesulitan memantau aktivitas pembelajaran peserta didik secara langsung. Berbeda ketika pembelajaran dilangsungkan di sekolah, guru dapat memastikan peserta didik dapat mengikuti jadwal pembelajaran yang ditetapkan. Oleh karena itu, guru perlu mencari solusi terkait bagaimana cara mengertahui kedisiplinan peserta didik dalam melaksanakan pembelan daring di rumah. Tujuan artikel ini adalah untuk 1) mendiskripsikan kedisiplinan belajar dalam pembelajaran online, 2) media pembelajaran google sites pada pembelajaran online, 3) pengaruh media pembelajaran google sites terhadap kedisiplinan peserta didik pada pembelajaran online. Hasil penelitian ini adalah 1) Kedisiplinan belajar berasal dari ranah afektif, yang termasuk salah satu poin dari nilai integritas, yang masuk pada ranah Penguatan Pendidikan Karakter (PPK), 2) Media pembelajaran google sites dapat meningkatkan kedisiplinan belajar melalui jadwal pembelajaran dan jam belajar yang dicantumkan, serta dapat memantau kedisiplinan kehadiran, menyimak materi, serta pengumpulan tugas yang diberikan.
\end{abstract}

Kata kunci: Kedisiplinan belajar, media pembelajaran, google sites 


\section{PENDAHULUAN}

Pendidikan merupakan komponen yang sangat penting dalam pembangunan nasional. Pendidikan nasional bertujuan seperti yang dirumuskan pembukaan UU No. 20 Tahun 2003 pasal 3 yaitu berkembangnya potensi peserta didik agar menjadi manusia yang beriman dan bertaqwa kepada Tuhan Yang Maha Esa, berakhlak mulia, sehat, berilmu, cakap, kreatif, mandiri, dan menjadi warga negara yang demokratis serta bertanggung jawab. Tujuan pendidikan nasional ini harus diupayakan perwujudannya dalam situasi serta kondisi apapun, demi kemajuan bangsa.

Pada era pandemi covid-19 ini pembelajaran dilakukan dengan acuan peraturan yang dikeluarkan oleh Kementerian Pendidikan dan Kebudayaan menerbitkan Surat Edaran No. 15 tahun 2020 yang melengkapi Surat Edaran No. 4 Tahun 2020 tentang pedoman penyelenggaraan pembelajaran di era darurat Covid-19. Tujuan penerbitan aturan tersebut adalah memenuhi hak peserta didik untuk mendapatkan akses pelayanan pendidikan selama pandemi. Aturan tersebut mengatur pembelajaran di sekolah selama pandemi dilakukan dengan sistem BDR (Belajar dari Rumah) atau pembelajaran jarak jauh.

Kurniasari (2020) mengatakan prinsip belajar dari rumah yakni peserta didik dapat belajar melalui akses materi dan sumber belajar tanpa batasan tempat dan waktu. Hal ini merupakan nilai lebih dari sistem BDR, artinya peserta didik dapat mengakses bahan pembelajaran di mana pun dan kapan pun secara fleksibel. Pada pembelajaran dengan sistem BDR, guru dapat memanfaatkan berbagai platform pembelajaran online untuk menyajikan bahan pembelajaran maupun kegiatan pembelajaran melalui media yang mudah diakses peserta didik. Khususnya pada jenjang Pendidikan sekolah dasar yang umumnya peserta didik baru mulai belajar menggunakan teknologi dalam pembelajaran.

Menurut Fauzi, M.I. (2013:45) pendidikan di jenjang pendidikan dasar yang berorientasi pada masa depan menghendaki keseimbangan pada tiga aspek (kognitif, afektif, psikomotor), artinya diperlukan kegiatan pembinaan sikap dan tingkah laku peserta didik untuk menentukan tingkah laku peserta didik. Salah satu hal yang ditekankan di dunia pendidikan saat ini adalah Penguatan Pendidikan Karakter (PPK). Salah satu nilai yang ditekankan dalam Pendidikan karakter adalah nilai integritas. Nilai integritas inti meliputi tiga hal yakni jujur, tanggung jawab, dan disiplin. Perilaku disiplin merupakan sikap mental menghargai waktu, yakni melakukan sesuatu dengan sungguh-sungguh sesuai dengan waktu yang ditetapkan. Kedisiplinan belajar pada era pandemi ini sulit diukur dan menjadi suatu momok permasalahan serius ketika pembelajaran sistem BDR.

Kelemahan pembelajaran melalui BDR yang sering ditemui guru antara lain : 1) fasilitas handphone yang masih bergabung dengan orangtua, 2) tidak semua peserta didik mempunyai kuota internet, 3) kendala jaringan internet karena letak geografis tempat tinggal peserta didik, serta 4) guru hanya dapat memantau pembelajaran secara jarak jauh dengan sistem online. Permasalahan fasilitas hp dapat diatasi dengan peserta didik bergabung dengan teman terdekat yang memiliki gawai. Permasalahan kuota internet dapat diatasi dengan adanya bantuan kuota belajar yang diberikan secara berkala dari program kemendikbud. Permasalahan jaringan tersendat karena letak geografis dapat ditangani dengan mencari lokasi yang sinyal internetnya stabil.

Permasalahan ke empat tentang pemantauan peserta didik dalam pembelajaran secara jarak jauh jarang dapat terpecahkan karena jarak yang memisahkan antara guru dan peserta didik. Hal tersebut terkadang membuat pembelajaran menjadi kurang efektif. Berbeda ketika pembelajaran dilangsungkan di sekolah dengan sistem tatap muka, guru dapat berinteraksi dengan peserta didik secara langsung dan memastikan peserta didik dapat mengikuti jadwal pembelajaran yang ditetapkan. Perubahan 
tersebut tentu berpengaruh dengan tingkat kedisiplinan peserta didik selama pelaksanaan BDR.

Menurut Majid, F.A. (2019:1) memaparkan pembelajaran jarak jauh melalui platform online membutuhkan kedisiplinan peserta didik untuk menganalisis apa saja yang harus dilakukan dan tugas mana saja yang harus diselesaikan. Pada sistem BDR dengan pencantuman jadwal secara garis besar yang hanya menyebutkan hari, tema, serta materi yang diajarkan peserta didik cenderung menunda mengumpulkan tugas asal tetap di hari yang sama. Banyak peserta didik yang kurang memahami konteks BDR sebenarnya sama dengan pembelajaran yang dilakukan di sekolah, namun hanya sistem penyelenggaraannya yang dilakukan secara online. Kedisiplinan belajar peserta didik menjadi permasalahan yang umum terjadi ketika perubahan pelaksanaan tatap muka menjadi pelaksanaan BDR.

Sugiarto (2019 : 233) menjelaskan sikap disiplin dalam belajar merupakan kunci keberhasilan pada kegiatan pembelajaran. Sikap disiplin belajar inilah yang nantinya memperkuat pendidikan karakter pada peserta didik sebagai bekal kelak di masa depan. Bentuk kedisiplinan yang harus dilakukan peserta didik adalah mengikuti pembelajaran dengan baik, melakukan presensi tepat waktu, menyimak materi yang disajikan oleh guru, serta melakukan dan mengerjakan tugas yang diberikan oleh guru yang harus diselesaikan tepat waktu. Melalui sikap disiplin belajar yang konsisten hasil belajar diharapkan akan lebih optimal, sehingga tujuan pembelajaran yang dirumuskan di kelas akan tercapai.

Berdasarkan paparan di atas menunjukkan bahwa tingkat kedisiplinan belajar peserta didik dalam sistem BDR menurun jika dibandingkan dengan sistem pembelajaran konvensional di sekolah dengan tatap muka. Oleh karena itu diperlukan inovasi sebuah pendekatan, metode, model, atau media pembelajaran yang dapat meningkatkan kedisiplinan belajar peserta didik sekaligus tidak menimbulkan kejenuhan dan lebih menyenangkan selama pelaksanaan program belajar dari rumah. Salah satu cara meningkatkan kedisiplinan belajar peserta didik adalah melalui media pembelajaran google sites.

Mukti, W.M (2020:52) mengungkapkan bahwa media pembelajaran dapat dibuat dengan menggunakan teknologi yang berkembang saat ini dengan tujuan untuk menyalurkan pesan kepada peserta didik sekaligus untuk merangsang pikiran, perasaan, dan minat belajarnya. Google sites merupakan salah satu media pembelajatan berbasis websites yang dapat menggabungkan berbagai informasi seperti teks, gambar, presentasi, video, lampiran link dan lain sebagainya. Menu pada google sites dapat diolah sedemikian rupa sesuai dengan tujuan pembelajaran yang ingin dicapai. Pemanfaatan google sites untuk meningkatkan kedisiplinan belajar peserta didik dapat dilakukan dengan mencantumkan jadwal pembelajaran serta mengkombinasikan menu yang berada pada google sites untuk menyampaikan materi pembelajaran, sehingga peserta didik lebih memahami tentang disiplin waktu dan tanggung jawab atas apa yang harus dilakukan dan dikerjakan dalam pembelajaran.

\section{HASIL DAN PEMBAHASAN}

Pada bagian hasil dan pembahasan akan dibahas tentang 1) kedisiplinan belajar peserta didik pada pembelajaran online, 2) media pembelajaran google sites untuk pembelajaran online, serta 3) hubungan kedisiplinan belajar pada pembelajaran online dengan media pembelajaran google sites.

\section{A. Kedisiplinan belajar peserta didik pada pembelajaran online}

Kedisiplinan diartikan oleh Harling, V.N.V (2020:2) adalah kepatuhan untuk menaati dan melaksanakan peraturan yang telah ditetapkan. Artinya, peserta didik yang disiplin adalah peserta didik yang taat dan patuh aturan yang ditetapkan oleh sekolah. Salah satu bentuk kedisiplinan dalam melaksanakan peraturan sekolah 
adalah disiplin melaksanakan jam belajar yang ditetapkan di sekolah dan mengikuti pembelajaran sesuai aturan yang berlaku, hal ini disebut kedisiplinan belajar. Menurut Rauqillah, D.R (2018:175) mengatakan kedisiplinan dalam belajar merupakan upaya menumbuhkan disiplin membangun semangat dengan kesadaran diri sendiri. Tujuan kedisiplinan belajar menurut Akmaluddin (2019:2) cara membantu peserta didik untuk memberikan pengendalian diri atau batasan selama mengikuti proses belajar mengajar. Peserta didik yang mempunyai kedisiplinan belajar mempunyai pengendalian diri yang kuat untuk mengikuti setiap proses pembelajaran yang ditetapkan dengan baik. Pada pembelajaran online kedisiplinan belajar peserta didik juga harus dilatih dan dibiasakan.

Indikator kedisiplinan belajar menurut Indianti, R (2017:70) yang dapat dimanfaatkan pula pada pembelajaran dari rumah (BDR) dengan sistem online antara lain :

1. Peserta didik disiplin ketika pembelajaran berlangsung

Pada indikator ini kedisiplinan belajar peserta didik dapat dilihat dari kedisiplinan waktu peserta didik saat memulai pembelajaran, disiplin dalam mengisi daftar hadir, mengikuti kegiatan sesuai dengan jadwal pembelajaran yang ditetapkan, mengikuti pembelajaran dengan tertib hingga pembelajaran selesai.

2. Peserta didik disiplin memanfaatkan fasilitas pembelajaran yang disediakan guru

Pada indikator ini kedisiplinan peserta didik dapat dilihat dari kedisiplinan peserta didik menyimak materi yang disajikan guru melalui sumber belajar yang diberikan, menggunakan media pembelajaran yang disiapkan guru, menyimak media pembelajaran yang disajikan guru, dan menggunakan segala fasilitas yang diberikan guru untuk memudahkan pembelajaran dengan baik.

3. Peserta didik disiplin mengumpulkan tugas

Kedisiplinan belajar peserta didik dalam mengumpulkan tugas dapat dilihat dari memperhatikan arahan penugasan yang disampaikan guru, mengerjakan tugas dengan sungguh-sungguh, dan ketepatan waktu peserta didik dalam pengumpulan tugas,

4. Peserta didik disiplin mengerjakan soal evaluasi

Kedisiplinan belajar peserta didik dilihat dari indikator tersebut adalah mengerjakan soal evaluasi sesuai perintah yang ditetapkan, mengerjakan soal evaluasi dengan sungguh-sungguh, dan mengerjakan evaluasi sesuai waktu yang ditetapkan.

B. Media Pembelajaran Google Sites untuk Pembelajaran Online

Media pembelajaran diartikan Wahid, A (2018:3) sebagai apa pun yang dapat dimanfaatkan untuk menyampaikan pesan pembelajaran yang dapat merangsang pikiran, perhatian, perasaan, serta kemampuan peserta didik. Media pembelajaran yang digunakan guru harus disesuaikan dengan kondisi dan karakteristik peserta didik. Pada masa pembelajaran di era pandemi dengan sistem pembelajaran jarak jauh, media pembelajaran berbasis teknologi diperlukan sebagai pengantar pesan pembelajaran. Miftah M (2014:2) mengemukakan bahwa aplikasi media pembelajaran berbasis teknologi meliputi penyediaan materi ajar, pemanfaatan berbagai jenis media pembelajaran, serta memposisikan media pembelajaran sebagai suatu bagian dari sistem pembelajaran yang utuh.

Media pembelajaran google sites merupakan salah satu fitur pembelajaran yang disediakan oleh google. Mukti, W.M (2020:52) menjelaskan media pembelajaran google sites merupakan media pembelajaran berbasis website yang dapat dimanfaatkan untuk memadukan banyak informasi. Guru sebagai fasilitator pembelajaran sangat mungkin mengembangkan google sites untuk dimanfaatkan sesuai dengan jenis kebutuhan dalam pembelajaran. 
Kelebihan google sites sebagai media pembelajaran antara lain :

1. Fitur dalam google sites sangat lengkap

Fitur lengkap yang dapat dimanfaatkan dalam google sites antara lain :

a. Menu penulisan teks untuk menjelaskan materi pembelajaran, menuliskan jadwal pembelajaran, serta menuliskan petunjuk dalam pembelajaran;

b. Menu penyisipan gambar untuk menarik peserta didik

c. Menu untuk menyisipkan video youtube untuk materi berupa video.

d. Menu untuk menyisipkan google form yang dimanfaatkan untuk presensi, LKPD, dan evaluasi;

e. Menu untuk menyisipkan link google meet untuk pertemuan online;

f. Menu kalender untuk menyematkan agenda dan tanggal dalam pembelajaran;

g. Menu menyisipkan power point untuk menyisipkan materi pembelajaran yang disajikan pada slide;

h. Menu menyematkan excel untuk menambahkan tabel dalam google sites; serta masih banyak menu lain yang dapat dikembangkan pemanfaatannya.

2. Google sites mudah digunakan di mana pun dan kapan pun

Media pembelajaran google sites dapat diakses peserta didik baik di rumah maupun di luar rumah dan peserta didik bebas mengakses materi setiap saat.

3. Karya peserta didik juga dapat ditampilkan pada google sites

Sementara kekurangan google sites adalah harus memerlukan akses internet. Namun, permasalahan tersebut dapat diatasi karena adanya bantuan kuota secara berkala oleh kemendikbud. Peserta didik yang sedang tidak memiliki kuota internet juga dapat bergabung dengan teman terdekat untuk mengikuti pembelajaran melalui google sites.

\section{Hubungan Kedisiplinan Belajar Peserta Didik pada Pembelajaran Online dengan Media Pembelajaran Google Sites}

Kedisiplinan peserta didik dalam pembelajaran online dapat ditingkatkan dengan implementasi media pembelajaraan google sites diantaranya sebagai berikut :

1. Kedisiplinan waktu kehadiran pembelajaran peserta didik diukur dengan melihat kehadiran peserta didik pada salah satu fitur google sites yaitu google meet pembuka pembelajaran, inti pembelajaran, dan penutup pembelajaran.

2. Kedisiplinan melakukan presensi dapat ditingkatkan dengan menyisipkan google form secara terbuka pada google sites.

3. Untuk meningkatkan kedisiplinan peserta didik mengikuti pembelajaran sesuai dengan jam pembelajaran yang ditetapkan, jadwal pembelajaran yang terdiri atas kegiatan serta waktu pembelajaran dapat dicantumkan pada google sites.

4. Kedisiplinan peserta didik mengikuti pembelajaran hingga selesai dapat diketahui dengan rekap akhir dari presensi kehadiran, daftar hadir google meet, peserta didik yang menyimak materi, mengerjakan tugas, serta soal evaluasi yang tercantum semua pada google sites.

5. Kedisiplinan peserta didik memanfaatkan fasilitas pembelajaran berupa materi pembelajaran dapat dilihat dari banyaknya viewers dan komentar youtube materi pembelajaran yang disajikan pada google sites.

6. Kedisiplinan mengumpulkan tugas dapat ditingkatkan melalui penyisipan LKPD online yang berbentuk seperti word wall, live work sheet, bahkan google form yang dimodifikasi sebagai LKPD. Kedisiplinan peserta didik dilihat dari rekap LKPD online yang dapat mendeteksi, ketepatan peserta didik memahami perintah tugas yang berpengaruh pada ketepatan jawaban peserta didik dan ketepatan waktu pengumpulan tugas. 
7. Kedisiplinan mengerjakan soal evaluasi ditingkatkan dengan memanfaatkan jenis-jenis alat evaluasi digital seperti google form, quizizz, kahoot , mentimeter, dan lain sebagainya. Alat evaluasi online tersebut dapat mendeteksi tingkat kepahaman peserta didik terhadap soal yang diberikan yang dapat dilihat dari ketepatan jawaban serta mendeteksi ketepatan waktu peserta didik dalam mengerjakan soal evaluasi.

\section{SIMPULAN}

Kedisiplinan belajar berasal dari ranah afektif, yang termasuk bagian nilai integritas, yang merupakan aspek penting pada Penguatan Pendidikan Karakter (PPK). Implementasi media pembelajaran google sites dapat meningkatkan kedisiplinan belajar peserta didik pada pembelajaran online melalui jadwal pembelajaran dan jam belajar yang dicantumkan. Melalui google sites kedisiplinan peserta didik dalam kehadiran, menyimak materi, serta mengumpulan tugas yang diberikan dapat dilihat dan ditinjau melalui berbagai fitur lengkap yang dapat dimanfaatkan guru dalam pembelajaran. Sehingga diharapkan dengan google sites pada pembelajaran online peserta didik dapat terbiasa bersikap disiplin dalam belajar dan tujuan pembelajaran dapat tercapai.

\section{DAFTAR PUSTAKA}

Akmaluddin. (2019). Kedisiplinan Belajar Siswa di Sekolah Dasar (SD) Negeri Cot Keu Eung Kabupaten Aceh Besar (Studi Kasus). Aceh : Journal of Education Science (JES). Vol 5 No 2

Fauzi, M.I. (2013). Hubungan Kedisiplinan Belajar di Rumah dan di Sekolah dengan Prestasi Belajar IPA Siswa Kelas IV SD Se-gugus Dewi Sartika. Yogyakarta : Jurnal Dinamika Pendidikan Dasar. Vol 8 No 1, Pp 45-49

Harling, V. N. V. (2020). Analisis Hubungan Kedisiplinan Belajar Dari Rumah (BDR) Dengan Prestasi Belajar Kimia Siswa Selama Masa Pandemi. Sorong : Socied (Journal Social, Science, and Education). Vol 3 No 2

Indrianti, R. (2020). Pengaruh Motivasi dan Disiplin Belajar Terhadap Hasil Belajar Mata Pelajaran Prakarya Dan Kewirausahaan. Jember : Jurnal Pendidikan Ekonomi: Jurnal IImiah IImu Pendidikan, IImu Ekonomi, dan IImu Sosial. Vol 11 No 2

Kementrian Pendidikan dan Kebudayaan RI. (2020). Surat Edaran tentang pedoman penyelenggaraan pembelajaran di era darurat Covid-19 (Surat Edaran Nomor 15 Tahun 2020). Jakarta : Penulis

Kurniasari. (2020). Analisis Efektivitas Pelaksanaan Belajar Dari Rumah (BDR) Selama Pandemi Covid-19. Surabaya : Jurnal Review Pendidikan Dasar: Jurnal Kajian Pendidikan dan Hasil Penelitian. Vol 6 No 2

Lisman, F. (2021). Kelebihan dan Kekurangan Sistem Pembelajaran Daring dari Perspektif Guru dan Siswa di SMK Negeri 2 Payakumbuh. Padang : Jurnal Vokasi Mekanika Universitas Negeri Padang. Vol 3 No 1

Majid, F.A. (2020). Kedisiplinan Belajar Peserta Didik Dalam Pembelajaran Jarak Jauh (Study From Home) Pada Masa Darurat Covid-19 di SMP Muhammadiyah 9 Yogyakarta Tahun Ajaran 2019/2020. Yogyakarya : Repository Universitas Ahmad Dahlan.

Miftah, M. (2014). Pemanfaatan Media Pembelajaran untuk Peningkatan Kualitas Belajar Siswa. Jakarta : Jurnal Kwangsan. Vol 2 No 1

Mukti, W.M. (2020). Optimalisasi Pendidikan dalam Rekontruksi Pembelajaran Berbasis Sains dan Teknologi Era New Normal. Surakarta : Jurnal unej. Vol 1 No 1 
Volume 9 Nomor 1 Tahun 2021

Rauqillah, D.R. (2018). Hubungan Antara Kedisiplinan dalam Belajar dengan Hasil Belajar Siswa Kelas V Di MI Al-Falah Cibinong Kabupaten Bogor. Bogor : Attadib Journal Of Elementary Education. Vol 3 No 2

Sugiarto. (2019). Faktor Kedisiplinan Belajar pada Siswa Kelas X SMK Larenda Brebes. Semarang : Jurnal Mimbar Ilmu. Vol 24 No 2, Pp 232-238

Wahid, A. (2018). Pentingnya Media Pembelajaran dalam Meningkatkan Prestasi Belajar. Pare-pare : Jurnal Pendidikan dan Pemikiran Islam Istira'. Vol 8 No 2 